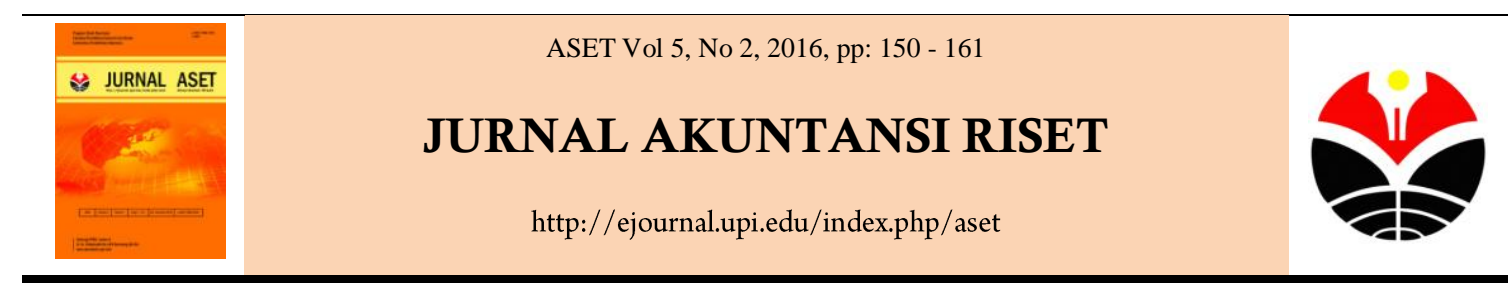

\title{
PENGARUH EKSTENSIFIKASI PAJAK DAN KEPATUHAN WAJIB PAJAK TERHADAP PENERIMAAN PAJAK PENGHASILAN WAJIB PAJAK ORANG PRIBADI (STUDI PADA KPP PRATAMA BANDUNG KAREES TAHUN 2010- 2015)
}

\author{
Faesal Fazlurahman ${ }^{1}$ \\ Universitas Pendidikan Indonesia. Bandung \\ Memen Kustiawan ${ }^{2}$ \\ Universitas Pendidikan Indonesia. Bandung
}

\section{Info Artikel Abstrak}

Diterima : 18-08-2016 Penelitian ini bertujuan untuk mengetahui apakah terdapat pengaruh ekstensifikasi Direvisi :29-08-2016 pajak dan kepatuhan Wajib Pajak secara parsial maupun simultan terhadap Diterbitkan : 18-09-2016 penerimaan pajak penghasilan Wajib Pajak Orang Pribadi.Penelitian ini menggunakan data sekunder yang diperoleh dari Kantor Pelayanan Pajak (KPP) Pratama Bandung Karees. Metode penelitian yang digunakan dalam penelitian ini

Keywords: Ekstensifikasi Pajak; Kepatuhan Wajib Pajak; dan Penerimaan pajak Penghasilan Wajib Orang Pribadi. adalah metode analisis deskriptif kuantitatif. Metode analisis data yang digunakan adalah uji asumsi klasik dan selanjutnya pengujian hipotesis. Metode statistik yang digunakan adalah analisis regresi linear berganda. Hasil penelitian menunjukkan bahwa secara parsial, tidak terdapat pengaruh positif ekstensifikasi pajak terhadap penerimaan pajak penghasilan Wajib Pajak Orang Pribadi. Hasil penelitian menunjukkan bahwa secara parsial, terdapat pengaruh positif kepatuhan Wajib Pajak terhadap penerimaan pajak penghasilan Wajib Pajak Orang Pribadi. Hasil penelitian menunjukkan bahwa secara simultan, terdapat pengaruh positif ekstensifikasi pajak dan kepatuhan Wajib Pajak terhadap penerimaan pajak penghasilan Wajib Pajak Orang Pribadi pada Kantor Pelayanan Pajak (KPP) Pratama Bandung Karees

(C) Jurnal Akuntansi Riset. Program Studi Akuntansi. FPEB. UPI

\footnotetext{
Alamat korespondensi :

${ }^{1}$ Program Studi Akuntansi. FPEB. Universitas Pendidikan Indonesia

E-mail (ffazlurahman8@gmail.com)

${ }^{2}$ Program Studi Akuntansi. FPEB. Universitas Pendidikan Indonesia

E-mail (memen.kustiawan@upi.edu)

2541-0342(elektronik) 2086-2563 (cetak)
}

\section{PENDAHULUAN}

Pajak sebagai sumber utama penerimaan negara, digunakan untuk membiayai pengeluaran rutin maupun pembangunan. Oleh karena itu, penerimaan dari sektor pajak ini diharapkan semakin meningkat dari tahun ke tahun. Walaupun penerimaan pajak selalu menjadi penyumbang penerimaan terbesar yang diterima oleh negara, pada kenyataannya berdasarkan perhitungan realisasi penerimaan pajak selama 2015 menurut Kementerian Keuangan tercatat 
mencapai Rp 1.055 triliun, dari target yang dipatok dalam Anggaran Pendapatan dan Belanja Negara (APBN) Perubahan 2015, yakni Rp 1.294 triliun, maka dapat dikatakan realisasi tersebut kurang sekitar Rp 234 triliun (suara.com, 2016).

Padahal Peluang untuk meningkatkan penerimaan pajak khususnya pajak penghasilan orang pribadi sebenarnya terbuka lebar. Berdasarkan data pada tahun 2014, jumlah penduduk Indonesia yang memiliki penghasilan di atas Penghasilan Tidak Kena Pajak (PTKP) ada sebanyak 44,8 juta orang. Namun demikian, baru 26,8 juta orang di antaranya yang telah terdaftar sebagai Wajib Pajak. Dari jumlah tersebut, hanya 10,3 juta Wajib Pajak yang menyampaikan SPT (kemenkeu.go.id, 2015). Berdasarkan fenomena tersebut dapat dikatakan bahwa upaya ekstensifikasi pajak yang dilakukan oleh Direktorat Jendral Pajak masih dapat dimaksimalkan.

Selain pelaksanaan ekstensifikasi yang belum optimal, Kepatuhan Wajib Pajak yang masih rendah dalam memenuhi kewajiban perpajakannya menjadi penyebab penerimaan pajak meleset pada tahun 2015. Sebagaimana yang dikemukakan oleh Menteri Keuangan Bambang Brodjonegoro "Tak tercapainya target penerimaan pajak masih disebabkan kepatuhan Wajib Pajak" (republika.co.id, 2015). Hal ini dapat dilihat dari data Ditjen Pajak per 2013 total Wajib Pajak terdaftar sebanyak 25.857.390 yang terdiri atas 2.218.573 Wajib Pajak badan, 555.995 Wajib Pajak bendahara, dan sisanya Wajib Pajak perorangan. Namun, dari total 24 juta, yang menyampaikan Surat Pemberitahuan pajak hanya 17 juta (republika.co.id, 2015). Berdasarkan fenomena tersebut mengindikasikan bahwa realisasi penerimaan pajak sangat dipengaruhi oleh faktor Kepatuhan Wajib Pajak, terutama Kepatuhan Wajib Pajak orang pribadi dalam melaksanakan kewajiban perpajakannya.

Dina fitriani (2009) menyatakan berdasarkan hasil penelitian menyimpulkan bahwa jumlah WP OP yang terdaftar, SSP yang diterima, ekstensifikasi WP, dan rasio pencairan tunggakan pajak secara parsial dan simultan memiliki pengaruh yang signifikan terhadap jumlah penerimaan Pajak Penghasilan orang pribadi di wilayah kerja Kantor Pelayanan Pajak (KPP) Batu. Patar (2015) menyatakan berdasarkan hasil penelitian menyimpulkan bahwa Kepatuhan Wajib Pajak Orang Pribadi berpengaruh terhadap Penerimaan Pajak Penghasilan Orang Pribadi Pada Kantor Pelayanan Pajak (KPP) Pratama Cibinong. Akan tetapi sebaliknya, Windy (2014) menyatakan berdasarkan hasil penelitian menyimpulkan bahwa Ekstensifikasi pajak dan Kepatuhan Wajib Pajak Orang Pribadi tidak berpengaruh terhadap Penerimaan Pajak Penghasilan pasal 21 di Kantor Pelayanan Pajak (KPP) Cibeunying.

Berdasarkan latar belakang dan fenomena yang ada, maka pada penelitian ini penulis merumuskan masalah apakah ekstensifikasi pajak berpengaruh terhadap penerimaan pajak penghasilan wajib pajak orang pribadi di KPP Pratama Bandung Karees, apakah kepatuhan wajib pajak berpengaruh terhadap penerimaan pajak penghasilan wajib pajak orang pribadi di KPP Pratama Bandung Karees, dan apakah ekstensifikasi pajak dan kepatuhan wajib pajak berpengaruh terhadap penerimaan pajak penghasilan wajib pajak orang pribadi di KPP Pratama Bandung Karees. Dan tujuan penelitian ini adalah untuk mengetahui pengaruh ekstensifikasi pajak terhadap penerimaan pajak penghasilan wajib pajak orang pribadi di KPP Pratama Bandung Karees, untuk mengetahui pengaruh kepatuhan wajib pajak terhadap penerimaan pajak penghasilan wajib pajak orang pribadi di KPP Pratama Bandung Karees, untuk mengetahui pengaruh ekstensifikasi pajak dan kepatuhan wajib pajak terhadap penerimaan pajak penghasilan wajib pajak orang pribadi di KPP Pratama Bandung Karees. 


\section{KAJIAN LITERATUR}

\section{Teori penghubung}

Berbeda dengan tarif pajak yang bersifat tetap sesuai undang-undang, upaya ekstensifikasi dan intensifikasi lebih bersifat kebijakan yang setiap saat dapat disesuaikan. Apabila langkah ini dilakukan dengan efisien tentu penerimaan pajak akan optimal (Simanjuntak, 2012, hlm. 28).

Menurut Widi Widodo (2010, hlm. 67) menjelaskan Jika angka kepatuhan pajak rendah maka secara otomatis akan berdampak pada rendahnya penerimaan pajak sehingga menurunkan tingkat penerimaan APBNpula.

Menurut Suparmono (2010, hlm. 2) dalam kaitannya dengan fungsi budgetair, pemerintah selalu berupaya untuk meningkatkan penerimaan negara yang ditempuh melalui ekstensifikasi dan intensifikasi pemungutan pajak. ekstensifikasi ditempuh melalui perluasan baik subjek maupun objek pajak, sedangkan intensifikasi ditempuh melalui peningkatan kepatuhan subjek pajak yang telah ada.

Ekstensifikasi Pajak

Menurut Slamet Irianto dalam bukunya yang berjudul Pajak Kepemimpinan Dan Masa Depan (2015, hlm. 171) menyatakan bahwa Ekstensifikasi adalah kegiatan yang dilakukan dalam rangka meningkatkan jumlah wajib pajak dan atau Pengusaha Kena Pajak (PKP) terdaftar serta untuk menghitung besarnya angsuran Pajak Penghasilan (PPh) dalam tahun berjalan dan penyetoran pajak dalam suatu masa pajak.

Menurut Surat Edaran DJP nomor SE-06/PJ.9/2001 tentang pelaksanaan ekstensifikasi pajak dan intensifikasi pajak, disimpulkan bahwa indikator ekstensifikasi pajak sebagai berikut :

1. Wajib Pajak terdaftar.

2. Penambahan jumlah Wajib Pajak terdaftar setiap tahun.

3. Peningkatan dengan adanya kegiatan pendataan objek pajak Kepatuhan Wajib Pajak

Menurut Siti Kurnia Rahayu dalam bukunya perpajakan (2013, hlm. 139) menyatakan bahwa Kepatuhan Perpajakan adalah tindakan wajib pajak dalam pemenuhan kewajiban perpajakannya sesuai dengan ketentuan peraturan perundang-undangan dan peraturan pelaksanaan perpajakan yang berlaku dalam suatu negara.

Berdasarkan SE-18/PJ/2006 tentang key performance indicator, menyebutkan bahwa Indikator kepatuhan Wajib Pajak dapat diukur dengan Perbandingan antara jumlah Wajib Pajak yang melaporkan SPT dengan jumlah Wajib Pajak yang terdaftar.

Penerimaan Pajak Penghasilan Orang Pribadi

Menurut Slamet Irianto dalam bukunya yang berjudul Pajak Kepemimpinan Dan Masa Depan (2015, hlm. 171) mengatakan bahwa Penerimaan Pajak adalah pemasukan yang paling potensial bagi negara, karena besarnya pajak seiring dengan laju pertumbuhan penduduk, perekonomian, dan stabilitas politik.

Menurut Siti Resmi dalam bukunya perpajakan indonesia (2011, hlm. 74) mendefinisikan bahwa Pajak Penghasilan adalah Pajak yang dikenakan terhadap subjek pajak atas penghasilan yang diterima atau diperolehnya dalam suatu tahun pajak. 
Menurut Mardiasmo dalam bukunya perpajakan (2014, hlm. 156) mendefinisikan orang pribadi adalah orang yang bertempat tinggal atau berada di Indonesia lebih dari 182 (seratus delapan puluh tiga) hari dalam jangka waktu 12 (dua belas) bulan dan yang dalam suatu tahun pajak berada di Indonesia dan mempunyai niat bertempat tinggal di Indonesia.

Berdasarkan definisi diatas dapat disimpulakan bahwa penerimaan pajak penghasilan orang pribadi adalah pemasukan yang paling potensial bagi negara yang dikenakan terhadap orang yang berada di Indonesia lebih dari 182 hari dalam jangka waktu 12 bulan dan dalam suatu tahun pajak berada di Indonesia yang menerima penghasilan dalam suatu tahun pajak.

Indikator Penerimaan Pajak berdasarkan SE-18/PJ/2006 tentang key performance indicator, menyebutkan bahwa indikator penerimaan pajak adalah perbandingan antara target penerimaan pajak dan realisasi penerimaan pajak.

\section{METODE PENELITIAN}

Objek penelitian ditemukan melekat pada subyek penelitian. Objek yang diteliti oleh penulis pada penelitian ini adalah upaya ekstensifikasi pajak, uepatuhan wajib pajak, dan penerimaan pajak penghasilan orang pribadi. penerimaan pajak penghasilan wajib pajak orang pribadi pada KPP Pratama Bandung Karees selama enam tahun terakhir tidak mencapai target yang ditetapkan. Hal tersebut yang menjadi alasan penulis melakukan penelitian di KPP Pratama Bandung Karees yang berlokasi di Jln. Ibrahim Adjie No. 372 Bandung.

Populasi dalam penelitian ini adalah penerimaan pajak penghasilan orang pribadi dan wajib pajak orang pribadi yang terdaftar di KPP Pratama Bandung Karees. Teknik sampling yang digunakan dalam penelitian ini adalah non-probability sampling dengan pendekatan sampling purposive. Berdasarkan metode purposive sampling data yang digunakan dalam penelitian yaitu :

1. Wajib Pajak Orang Pribadi terdaftar di KPP Pratama Bandung Karees selama tahun 2010-2015.

2. Wajib Pajak Orang Pribadi baru di KPP Pratama Bandung Karees selama tahun 20102015

3. Wajib Pajak Orang Pribadi setor SPT di KPP Pratama Bandung Karees selama tahun 2010-2015

4. Jumlah target dan realisasi penerimaan pajak penghasilan orang pribadi selama tahun 2010-2015

Penelitian ini menggunakan data sekunder bersumber dari seksi PDI dan seksi ekstensifikasi KPP Pratama Bandung Karees. Teknik pengumpulan data menggunakan teknik dokumentasi. Metode penelitian yang digunakan dalam penelitian ini adalah metode analisis deskriptif kuantitatif. Metode analisis data yang digunakan adalah uji asumsi klasik dan selanjutnya pengujian hipotesis. Metode statistik yang digunakan adalah analisis regresi linear berganda. 


\section{HASIL DAN PEMBAHASAN}

\section{Statistik Deskriptif}

Statistik deskriptif disajikan untuk memberikan informasi karakteristik variabel penelitian khususnya mengenai rata-rata (mean), maksimum, minimum dan standar deviasi.

Tabel 1

Hasil Uji Statistik Deskriptif

Statistics

\begin{tabular}{|c|c|c|c|}
\hline & $\begin{array}{c}\text { Penerimaan } \\
\text { PPh OP }\end{array}$ & $\begin{array}{c}\text { Ekstensifikasi } \\
\text { Pajak }\end{array}$ & $\begin{array}{l}\text { Kepatuhan } \\
\text { wajib Pajak }\end{array}$ \\
\hline Valid & 6 & 6 & 6 \\
\hline Missing & 0 & 0 & 0 \\
\hline Mean & .8417 & 8621.3333 & .5922 \\
\hline Std. Error of Mean & .09924 & 781.79732 & .03227 \\
\hline Median & .8930 & 7788.5000 & .5617 \\
\hline Mode & $.43^{\mathrm{a}}$ & $7237.00^{a}$ & $.52^{\mathrm{a}}$ \\
\hline Std. Deviation & .24310 & 1915.00451 & .07904 \\
\hline Variance & .059 & 3667242.267 & .006 \\
\hline Range & .71 & 5125.00 & .21 \\
\hline Minimum & .43 & 7237.00 & .52 \\
\hline Maximum & 1.14 & 12362.00 & .73 \\
\hline Sum & 5.05 & 51728.00 & 3.55 \\
\hline
\end{tabular}

Sumber : data diolah, 2016

Berdasarkan tabel di atas menjelaskan nilai statistik deskriptif dari masing - masing variabel yang ada dalam penelitian ini. Nilai rata-rata Penerimaan Pajak penghasilan Orang Pribadi adalah sebesar 0.8417 dengan nilai simpangan baku sebesar 0.243 menunjukkan bahwa tidak terdapat nilai ekstrem dalam data sedangkan nilai terkecil Penerimaan Pajak penghasilan Orang Pribadi yaitu 0.43 dan nilai terbesar Penerimaan Pajak penghasilan Orang Pribadi terbesar yaitu 1.14.

Nilai rata-rata upaya ekstensifikasi pajak selama 6 tahun terakhir adalah 8621 dengan nilai simpangan baku sebesar 781.8 menunjukkan bahwa tidak terdapat nilai ekstrem dalam data, nilai terkecil upaya ekstensifikasi pajak adalah sebesar 7237 yaitu pada tahun 2013 dan nilai terbesar ekstensifikasi pajak adalah sebanyak 12362 yaitu pada tahun 2010 .

Rata-rata kepatuhan pajak adalah 0.5922 dengan nilai simpangan baku 0.03227 menunjukkan bahwa tidak terdapat nilai ekstrem dalam data, nilai terkecil kepatuhan pajak adalah sebesar 0.52 dan nilai terbesar kepatuhan pajak adalah 0.73 . 
Tabel 2

Hasil Analisis Regresi Linier Berganda Coefficients $^{\mathrm{a}}$

\begin{tabular}{|c|c|c|c|}
\hline & \multirow[b]{2}{*}{ Model } & \multicolumn{2}{|c|}{$\begin{array}{l}\text { Unstandardized } \\
\text { Coefficients }\end{array}$} \\
\hline & & B & Std. Error \\
\hline \multirow[t]{3}{*}{1} & (Constant) & .599 & 1.370 \\
\hline & Ekstensifikasi Pajak & $-3.935 \mathrm{E}-5$ & .000 \\
\hline & Kepatuhan wajib Pajak & .982 & 1.675 \\
\hline
\end{tabular}

a. Dependent Variable: Penerimaan PPh OP

Sumber: data diolah, 2016

Berdasarkan output di atas didapat nilai kontstanta dan koefisien sehingga dibentuk persamaan regresi linier berganda sebagai berikut:

$$
\mathrm{Y}=0.599-0.393 \times 10^{-5} \mathrm{X}_{1}+0.982 \mathrm{X}_{2}
$$

Berdasarkan hasil analisis regresi linier berganda pada tabel 4.8 diatas dapat diinterpretasikan sebagai berikut :

1. Konstanta (a)

Nilai Konstanta (a) sebesar 0,599 menunjukkan bahwa apabila nilai variabel ekstensifikasi pajak dan kepatuhan Wajib Pajak konstan, maka nilai variabel penerimaan pajak penghasilan Wajib Pajak Orang Pribadi sebesar 0,599.

2. Koefisien ekstensifikasi pajak (b1) terhadap penerimaan pajak penghasilan Wajib Pajak Orang Pribadi (Y)

Berdasarkan hasil analisis regresi linier berganda pada tabel 4.8 diatas dapat dilihat bahwa Besarnya nilai koefisien regresi (b1) sebesar $-0.393 \times 10^{-5}$, nilai b1 negatif menunjukkan bahwa apabila ekstensifikasi pajak $\left(\mathrm{X}_{1}\right)$ meningkat sebesar 1 satuan, maka variabel penerimaan penerimaan pajakpenghasilan Orang Pribadi (Y) akan menurun sebesar $0.393 \times 10^{-5}$. Dengan asumsi variabel bebas lainnya konstan. Hal ini menunjukan $\mathrm{H}_{0}$ diterima dan $\mathrm{H}_{\mathrm{a}}$ ditolak, sehingga dapat diartikan bahwa tidak terdapat pengaruh positif ekstensifikasi pajak terhadap penerimaan pajak penghasilan Wajib Pajak Orang Pribadi.

3. Koefisien kepatuhan Wajib Pajak (b2) terhadap penerimaan pajak penghasilan Wajib Pajak Orang Pribadi (Y)

Berdasarkan hasil analisis pada tabel 4.9 diatas dapat dilihat bahwa Besarnya nilai koefisien regresi (b2) sebesar 0,982 , nilai b2 positif menunjukkan hubungan yang berbanding lurus antara variabel kepatuhan Wajib Pajak dengan variabel penerimaan pajak penghasilan Wajib Pajak Orang Pribadi yang artinya apabila nilai variabel kepatuhan Wajib Pajak naik sebesar 1 satuan maka nilai variabel penerimaan pajak penghasilan Wajib Pajak Orang Pribadi akan naik sebesar 0,982. Dengan asumsi variabel bebas lainnya konstan. $\mathrm{Hal}$ ini menunjukan $\mathrm{H}_{0}$ ditolak dan $\mathrm{H}_{\mathrm{a}}$ terima, sehingga dapat diartikan bahwa terdapat pengaruh positif kepatuhan Wajib Pajak terhadap penerimaan pajak penghasilan Wajib Pajak Orang Pribadi. 


\subsubsection{Koefisien determinasi}

Koefisien determinasi dihitung untuk mengetahui seberapa besar pengaruh kedua variabel independen yaitu ekstensifikasi pajak dan kepatuhan Wajib Pajak secara bersama-sama terhadap variabel dependen yaitu penerimaan pajak penghasilan Wajib Pajak Orang Pribadi. Nilai koefisien determinasi yang diperoleh melalui hasil pengolahan data menggunakan aplikasi IBM SPSS Statistic 20.0 for Windows dapat dilihat pada tabel 4.3 berikut:

Tabel 4.3

\section{Hasil Koefisien Determinasi}

\begin{tabular}{|c|r|r|r|r|r|}
\hline Model & \multicolumn{1}{|c|}{$\mathrm{R}$} & R Square & $\begin{array}{c}\text { Adjusted R } \\
\text { Square }\end{array}$ & $\begin{array}{c}\text { Std. Error of } \\
\text { the Estimate }\end{array}$ & $\begin{array}{c}\text { Durbin- } \\
\text { Watson }\end{array}$ \\
\hline 1 & $.535^{\mathrm{a}}$ & .286 & -.190 & .26514 & 2.171 \\
\hline
\end{tabular}

Berdasarkan hasil analisis diatas, dapat diketahui bahwa nilai koefisien determinasi mempunyai nilai sebesar $0.286>0$, atau lebih besar dari 0 . Hal ini menunjukan $\mathrm{H}_{0}$ ditolak dan $\mathrm{H}_{\mathrm{a}}$ diterima, sehingga dapat diartikan bahwa terdapat pengaruh positif ekstensifikasi pajak dan kepatuhan Wajib Pajak terhadap penerimaan pajak penghasilan Wajib Pajak Orang Pribadi.

Hal ini dapat diartikan bahwa secara bersama-sama upaya ekstensikasi pajak dan kepatuhan Wajib Pajak memberikan pengaruh sebesar 28.6\% terhadap penerimaan pajak penghasilan Orang Pribadi. Sedangkan sisanya sebesar $71.4 \%$ dipengaruhi oleh faktor lain yang tidak diamati di dalam penelitian ini.

\section{Pengaruh Ekstensifikasi Pajak Terhadap Penerimaan PPh OP}

Penelitian ini bertujuan untuk mengetahui pengaruh dari variabel ekstensifikasi pajak terhadap penerimaan pajak penghasilan Wajib Pajak Orang Pribadi pada KPP Pratama Bandung Karees. Untuk mengetahui pengaruh antara variabel tersebut peneliti menggunakan analisis regresi linier berganda. Ekstensifikasi pajak diukur dengan menghitung jumlah Wajib Pajak Orang Pribadi terdaftar baru sebagai Wajib Pajak pada KPP Pratama Bandung Karees. Hasil analisis menunjukkan bahwa semakin bertambahnya ekstensifikasi pajak terhadap Wajib Pajak Orang Pribadi maka akan menurunkan penerimaan pajak penghasilan Wajib Pajak Orang Pribadi pada KPP Pratama Bandung Karees. Hal tersebut dibuktikan berdasarkan hasil analisis regresi linier berganda yang menunjukan bahwa nilai koefisien ekstensifikasi pajak memiliki nilai sebesar $-0.393 \times 10^{-5}<0$, yang artinya bernilai negatif dan lebih kecil dari nol. Menunjukan bahwa apabila ekstensifikasi pajak $\left(\mathrm{X}_{1}\right)$ meningkat sebesar 1 satuan, maka variabel penerimaan penerimaan pajak penghasilan Orang Pribadi (Y) akan menurun sebesar $0.393 \times 10^{-5}$. maka hal ini dapat disimpulkan bahwa $\mathrm{H}_{0}$ diterima dan $\mathrm{H}_{\mathrm{a}}$ ditolak, yang artinya tidak terdapat pengaruh positif ekstensifikasi pajak terhadap penerimaan pajak penghasilan Wajib Pajak Orang Pribadi. Hal ini terjadi karena lemahnya penegakan hukum terhadap wajib pajak yang tidak patuh membayar pajak, kebijakan kenaikan Penghasilan Tidak Kena Pajak (PTKP) yang menyebabkan wajib pajak terdaftar yang penghasilan sebelumnya di atas PTKP menjadi dibawah PTKP sehingga banyak WP yang melapor SPT nihil, Kurangnya kesadaran 
masyarakat sebagai wajib pajak untuk membayar pajak, maraknya WP yang melakukan penggelapan pajak, dan ekstensifikasi ini harus disertai dengan intensifikasi pajak yang dilakukan dengan cara peningkatan kepatuhan subjek pajak yang telah ada sehingga pelaksanaan ekstensifikasi pajak dapat berjalan efektif. sebagaimana yang dikemukan Syafrianto (2007, hlm. 1) bahwa dalam meningkatkan penerimaan pajak upaya yang dilakukan berupa ekstensifikasi dan intensifikasi di bidang perpajakan, Direktorat Jenderal Pajak juga berusaha terus melakukan pembaharuan di bidang pelayanan terhadap masyarakat dengan menciptakan suatu modernisasi dalam administrasi perpajakan serta pengajuan perubahan Undang-Undang Perpajakan.

Penelitian ini mendukung penelitian yang dilakukan Windy Anggraeni (2014) berdasarkan hasil penelitiannya menyimpulkan bahwa ekstensifikasi pajak tidak berpengaruh terhadap Penerimaan Pajak Penghasilan pasal 21 di Kantor Pelayanan Pajak (KPP) Cibeunying. Kemudian, penelitian yang dilakukan Wella Adrianti (2013) yang menyatakan berdasarkan hasil penelitian menyimpulkan bahwa ekstensifikasi pajak tidak berpengaruh terhadap penerimaan pajak penghasilan Orang Pribadi di Kantor Pelayanan Pajak (KPP) Pratama Tanjung Pinang.

Hasil penelitian ini tidak sesuai dengan hasil penelitian yang dilakukan oleh Dina fitriani (2009) berdasarkan hasil penelitian menyimpulkan bahwa ekstensifikasi WP memiliki pengaruh yang signifikan terhadap jumlah penerimaan Pajak Penghasilan Orang Pribadi pada Kantor Pelayanan Pajak (KPP) Batu. Hasil penelitian ini juga tidak mendukung penelitian Ega Kurnia (2015) berdasarkan hasil penelitian menyimpulkan bahwa ekstensifikasi pajak berpengaruh signifikan terhadap penerimaan pajak penghasilan Orang Pribadi pada KPP Pratama Malang selatan.

\section{Pengaruh Kepatuhan WP Terhadap Penerimaan PPh OP}

Wajib Pajak terhadap penerimaan pajak penghasilan Wajib Pajak Orang Pribadi pada KPP Pratama Bandung Karees. Untuk mengetahui pengaruh antara variabel kepatuhan Wajib Pajak peneliti menggunakan analisis regresi linier berganda. Kepatuhan Wajib Pajak diukur dengan menghitung perbandingan Wajib Pajak Orang Pribadi terdaftar dengan Wajib Pajak yang menyetor SPT pada KPP Pratama Bandung Karees. Berdasarkan hasil pengujian dan pengolahan data secara statistik menunjukan bahwa nilai koefisien kepatuhan Wajib Pajak sebesar 0,982 >0, yang artinya bernilai positif dan lebih besar dari nol. Setiap adanya peningkatan sebesar satu pada kepatuhan Wajib Pajak maka akan meningkatkan penerimaan pajak penghasilan Wajib Pajak Orang Pribadi sebesar 0,982. maka dapat dikatakan $\mathrm{H}_{\mathrm{o}}$ ditolak dan $\mathrm{H}_{\mathrm{a}}$ diterima. artinya bahwa terdapat pengaruh positif variabel kepatuhan Wajib Pajak terhadap penerimaan pajak penghasilan Wajib Pajak Orang Pribadi. Hal ini sesuai teori yang dikemukakan oleh Siti Kurnia Rahayu dalam bukunya perpajakan indonesia (2013, hlm. 139) mengemukakan bahwa kepatuhan dalam pemenuhan kewajiban perpajakan yang sesuai dengan kebenaran, Sehingga kepatuhan diperlukan dalam self assesment system dengan tujuan untuk pada penerimaan pajak yang optimal. Kemudian sesuai teori yang dikemukakan oleh Widi Widodo (2010, hlm. 67) menjelaskan jika angka kepatuhan pajak rendah maka secara otomatis akan berdampak pada rendahnya penerimaan pajak sehingga menurunkan tingkat penerimaan APBNpula. Jadi dalam meningkatkan penerimaan pajak dalam hal ini pajak penghasilan Wajib Pajak Orang Pribadi dibutuhkan kepatuhan Wajib Pajak yang tinggi dalam memenuhi semua kewajiban perpajakanya. 
Hasil penelitian ini mendukung penelitian Patar (2015) yang menyatakan berdasarkan hasil penelitian menyimpulkan bahwa kepatuhan Wajib Pajak Orang Pribadi berpengaruh signifikan terhadap penerimaan pajak penghasilan Orang Pribadi pada Kantor Pelayanan Pajak (KPP) Pratama Cibinong. Kemudian sesuai dengan penelitian yang dilakukan oleh Divianto (2012) yang menunjukkan bahwa berdasarkan hasil penelitian menyimpulkan bahwa kepatuhan Wajib Pajak berpengaruh signifikan terhadap penerimaan pajak penghasilan Orang Pribadi pada Kantor Pelayanan Pajak Pratama Baturaja.

Hal ini tidak sesuai dengan penelitian yang dilakukan oleh Windy (2014) yang menyatakan berdasarkan hasil penelitian menyimpulkan bahwa kepatuhan Wajib Pajak Orang Pribadi tidak berpengaruh terhadap Penerimaan Pajak Penghasilan pada KPP Pratama Cibeunying. Kemudian, tidak sesuai dengan penelitian yang dilakukan oleh Wella Adrianti (2013) yang menyatakan berdasarkan hasil penelitian menyimpulkan bahwa kepatuhan Wajib Pajak Orang Pribadi tidak berpengaruh terhadap Penerimaan Pajak Penghasilan pada KPP Pratama Tanjung Pinang.

Pengaruh Ekstensifikasi Pajak Dan Kepatuhan WP Terhadap Penerimaan PPh OP

Penelitian ini bertujuan untuk mengetahui pengaruh variabel ekstensifikasi pajak dan kepatuhan Wajib Pajak secara bersama-sama terhadap penerimaan pajak penghasilan Wajib Pajak Orang Pribadi pada KPP Pratama Bandung Karees. Untuk mengetahui pengaruh variabel ekstensifikasi pajak dan kepatuhan Wajib Pajak peneliti menggunakan analisis koefisien determinasi. Berdasarkan hasil pengujian dan pengolahan data menggunakan analisis koefisien determinasi menunjukan bahwa nilai koefisien ekstensifikasi pajak dan kepatuhan Wajib Pajak secara bersama-sama mempunyai nilai sebesar 0,286 >0, yang artinya bernilai positif dan lebih besar dari nol. maka dapat dikatakan $\mathrm{H}_{\mathrm{o}}$ ditolak dan $\mathrm{H}_{\mathrm{a}}$ diterima. artinya bahwa terdapat pengaruh positif variabel ekstensifikasi pajak dan kepatuhan Wajib Pajak secara bersama-sama terhadap penerimaan pajak penghasilan Wajib Pajak Orang Pribadi. Hal ini sesuai teori yang dikemukakan Suparmono (2010, hlm. 2) yang menyatakan bahwa dalam kaitannya dengan fungsi budgetair, pemerintah selalu berupaya untuk meningkatkan penerimaan negara yang ditempuh melalui ekstensifikasi dan intensifikasi pemungutan pajak. ekstensifikasi ditempuh melalui perluasan baik subjek maupun objek pajak, sedangkan intensifikasi ditempuh melalui peningkatan kepatuhan subjek pajak yang telah ada.

Penelitian ini sesuai dengan penelitian yang dilakukan oleh Dina Fitriani (2009) yang berdasarkan hasil penelitian menyimpulkan bahwa ektensifikasi Wajib Pajak berpengaruh signifikan terhadap jumlah penerimaan pajak penghasilan Orang Pribadi. Kemudian, sesuai dengan penelitian yang dilakukan oleh Divianto (2012) yang menunjukkan bahwa berdasarkan hasil penelitian menyimpulkan bahwa kepatuhan Wajib Pajak berpengaruh terhadap penerimaan pajak penghasilan Orang Pribadi di Kantor Pelayanan Pajak Pratama Baturaja.

Hasil penelitian ini tidak sejalan dengan penelitian Windy (2014) berdasarkan hasil penelitiannya menyimpulkan bahwa ekstensifikasi pajak dan kepatuhan Wajib Pajak secara bersama-sama tidak berpengaruh terhadap penerimaan pajak penghasilan pasal 21 pada Kantor Pelayanan Pajak (KPP) Cibeunying dan juga tidak sesuai dengan penelitian Wella Adrianti (2013) yang menyatakan berdasarkan hasil penelitian menyimpulkan bahwa ekstensifikasi pajak dan kepatuhan Wajib Pajak Orang Pribadi tidak berpengaruh terhadap penerimaan pajak penghasilan pada KPP Pratama Tanjung Pinang. 


\section{SIMPULAN DAN SARAN}

\section{SIMPULAN}

Berdasarkan hasil analisis mengenai pengaruh ekstensifikasi pajak dan kepatuhan Wajib Pajak terhadap penerimaan pajak penghasilan Wajib Pajak Orang Pribadi pada KPP Pratama Bandung Karees, maka penulis dapat menarik kesimpulan sebagai berikut:

1. Berdasarkan hasil analisis regresi linier berganda untuk variabel ekstensifikasi pajak, menyatakan bahwa tidak terdapat pengaruh positif ekstensifikasi pajak terhadap penerimaan pajak penghasilan Wajib Pajak Orang Pribadi.

2. Berdasarkan hasil analisis regresi linier berganda untuk variabel kepatuhan Wajib Pajak, menyatakan bahwa terdapat pengaruh positif kepatuhan Wajib Pajak terhadap penerimaan pajak penghasilan Wajib Pajak Orang Pribadi.

3. Berdasarkan hasil analisis koefisien determinasi untuk variabel ekstensifikasi pajak dan kepatuhan Wajib Pajak, menyatakan bahwa terdapat pengaruh positif ekstensifikasi pajak dan kepatuhan Wajib Pajak terhadap penerimaan pajak penghasilan Wajib Pajak Orang Pribadi.

\section{SARAN}

Berdasarkan hasil penelitian dan kesimpulan yang telah diuraikan, ada beberapa hal yang dapat penulis sarankan:

1. Secara Praktis

Hasil penelitian ini menyimpulkan bahwa tidak terdapat pengaruh positif ekstensifikasi pajak terhadap penerimaan pajak penghasilan Wajib Pajak Orang Pribadi pada KPP Pratama Bandung Karees. Hal tersebut dapat dijadikan salah satu pertimbangan bagi KPP Pratama Bandung Karees untuk meningkatkan ekstensifikasi pajak dengan ditunjang upaya lain yaitu intensifikasi yang baik, penegakan hukum yang tegas, lebih meningkatkan sosialisasi kepada masyarakat, sistem pengawasan internal yang ketat.

2. Secara Akademis

Bagi peneliti selanjutnya, Penelitian ini hanya menggunakan variabel ekstensifikasi pajak dan kepatuhan Wajib Pajak. Untuk itu, sebaiknya menambahkankan variabel intensifikasi pajak dalam penelitian. Sedangkan keterbatasan pada penelitian ini terbatas pada pelaporan SPT yang masuk ke KPP Pratama Bandung Karees, sehingga akan lebih baik jika meneliti kepatuhan dilihat dari Wajib Pajak yang membayar pajak.

\section{DAFTAR PUSTAKA}

Adhitya, H. (2016). Realisasi Penerimaan Pajak Nasional Hari Ini Capai Rp170 Triliun. Tersedia : http://www.suara.com [16 Maret 2016]

Amina Lainutu, (2013). Pengaruh Jumlah Wajib Pajak Pph 21 Terhadap Penerimaan Pph 21 Pada Kpp Pratama Manado. Jurnal EMBA Vol. 1 Hal. 274-382.

Arikunto, S. (2013). Prosedur Penelitian : Suatu Pendekatan Praktik. Cetakan Kelimabelas. Jakarta : Rineka Cipta. 
Aurelia, dkk (2014). Analisis Faktor-Faktor Yang Mempengaruhi Penerimaan Pajak Penghasilan Wajib Pajak Orang Pribadi Pada Kpp Pratama Manado (2014). Jurnal EMBA Vol.2 No.4 Tahun 2014 ISSN : 2303-1174.

Bambang. (2015). Pemerintah Canangkan Tahun Pembinaan Wajib Pajak 2015. Tersedia : http://www.kemenkeu.go.id [29 April 2015]

Budi, C. (2014). Agenda pajak menteri keuangan. Tersedia : http://www. Tempo.co.id. [06 November 2014]

Darmawan. (2013). Metode Penelitian Kuantitatif. Bandung: Remaja Rosdakarya.

Divianto, (2012). Pengaruh Kepatuhan Wajib Pajak Orang Pribadi Terhadap Penerimaan Pajak Penghasilan Kpp Pratama Baturaja. Jurnal Akuntansi Vol. 3 No. 3 September 2013

Ferry, K. (2015). Wajib Pajak tak Patuh, Penerimaan Pajak Meleset. Tersedia : http://m.republika.co.id [ 9 April2015]

Fitriani, D. (2009). Analisis Faktor-Faktor Yang Mempengaruhi Jumlah Penerimaan Pajak Penghasilan Orang Pribadi Pada KPP Prtama Batu. Jurnal ekonomi Vol. 3. ISSN : 135149.

Ghozali, I. (2011). Aplikasi Analisis Multivariate Dengan Program IBM SPSS 19 (edisi kelima.) Semarang: Universitas Diponegoro.

Gujarati. (2003). Metode Penelitian Kuantitatif, Kualitatif dan R\&D. Bandung. Penerbit: Alfabeta.

Iqbal Hasan. (2008) . Analisis Data Penelitian Statistik. Jakarta: Bumi Aksara.

Irianto, E.S (2015). Pajak kepemimpinan dan masa depan. Semarang : Kantor Wilayah Direktorat Jendral Pajak Jawa Tengah

Irwan (2015). Wajib pajak membludak di KPP Pratama Bandung Karees. Tersedia : http://fokusjabar.com. [31 maret 2015]

Istijanto. (2009). Aplikasi Praktis Riset Pemasaran. Jakarta. Penerbit : Gramedia Pustaka Utama.

Kasiram, M. (2008). MetodePenelitianKuantitatif-Kualitatif. Malang: UIN-Malang Press.

Kuncoro, M. (2003). Metode Riset untuk Bisnis dan Ekonomi. Jakarta : Erlangga

Kurnia, E.S (2015). Efektivitas Kegiatan Ekstensifikasi Perpajakan Dalam Upaya Peningkatan Penerimaan Pajak Penghasilan Orang Pribadi Pada Kpp Pratama Malang Selatan. Jurnal Perpajakn Vol. 6 No. 2 Tahun 2015

Mardiasmo. (2014). Perpajakan. Edisi Revisi 2014. Yogyakarta : Penerbit Andi.

Marisa Herryanto dan Agus Arianto, (2012). Pengaruh Kesadaran Wajib Pajak, Kegiatan Sosialisasi Perpajakan, Dan Pemeriksaan Pajak Terhadap Penerimaan Pajak Penghasilan Di KPP Pratama Surabaya Sawahan. Jurnal Pajak dan Akuntansi Vol. 1 No. 12013.

Meilia, N.I. (2010). Statistik Deskriptif dan Induktif. Yogyakarta: Graha Ilmu.

Moch, Nazir. (2013). Metode Penelitian. Jakarta : Ghalia Indonesia.

Muljono, D. (2010). Panduan Brevet Pajak: Pajak Penghasilan.Yogyakarta: Penerbit Andi

Patar Simamora, (2012). Pengaruh Tingkat Kepatuhan Wajib Pajak Orang Pribadi Terhadap Penerimaan Pajak Penghasilan Orang Pribadi Pada Kpp Pratama Cibinong. Jurnal Perpajakan Vol. 1 No. 1 Tahun 2015 Hal. 25-31 ISSN : 2502-5678

Rahayu, S.K. (2013). Perpajakan Indonesia. Yogyakarta: Graha Ilmu. 
Republik Indonesia, Undang-UndangNomor 36 Tahun 2008 Tentang Perubahan Keempat Atas Undang-Undang Nomor 7 Tahun 1983 Tentang Pajak Penghasilan.

Resmi, S.( 2011). Perpajakan: Teori dan Kasus. Edisi Ke lima. Jakarta: Penerbit Salemba Empat

Simanjuntak, T.H. dan Muchlis, I. (2012). Dimensi Ekonomi Perpajakan Dalam Pembangunan Ekonomi. Jakarta. Penerbit : Raih Asa Sukses

Singgih, S. (2004). SPSS (statistical product and service solution). Jakarta : PT Elex Media Komputindo

Suandy, Erly. (2011). Hukum Pajak. Edisi 5. Jakarta: Salemba Empat.

Sudjana. (2005). Metode statistika. Bandung: Penerbit Tarsito.

Sugiyono. (2014). Metode penelitian bisnis. Bandung : Alfabeta

Sukestiyarno. (2014). Statistika Dasar. Yogyakarta: CV Andi Offset.

Suparmono. (2010). Perpajakan Indonesia. Jogjakarta. Penerbit: CV Andi Offset.

Surat Edaran Direktur Jenderal Pajak Nomor : SE - 51/PJ/2013 tentang Petunjuk Pelaksanaan Peraturan Direktur Jenderal Pajak Nomor Per-35/Pj/2013 Tentang Tata Cara Ekstensifikasi

Surat Edaran Direktur Jenderal Pajak Nomor SE-06/PJ.9/2001 tentang pelaksanaan ekstensifikasi Wajib Pajak dan Intensifikasi Pajak

Surat Edaran Direktur Jendral Pajak nomer SE-18/PJ/2006 tentang key performance indikator Suryadi. (2006). Model Hubungan Kausal Kesadaran, Pelayanan, Kepatuhan Wajib Pajak Dan Pengaruhnya Terhadap Kinerja Penerimaan Pajak. Jurnal Keuangan Publik, 4(1),105121.

Syafrianto, L.D. (2007). My Tax SPT-1770 S. Jakarta. Penerbit: PT Elex Media Kompetindo Widodo, W. (2010). Moralitas, Budaya dan Kepatuhan Pajak. Bandung: Alfabeta

Windy, dkk (2014) Pengaruh Ekstensifikasi Pajak dan Tingkat Kepatuhan Wajib Pajak Terhadap Penerimaan Pajak Penghasilan Pasal 21 pada Kantor Pelayan Pajak Pratama Cibeunying Bandung periode 2008-2013. Jurnal akuntansi ISSN : 2460-6561

Yoyok. (2016).Kanwil Jawa Barat 1 Tahun 2015 Raup Penerimaan 216 Triliun. Tersedia : http://www.pajak.go.id [7 Januari 2016] 